\title{
Simultaneous gonochoric spawning of Dendrogyra cylindrus
}
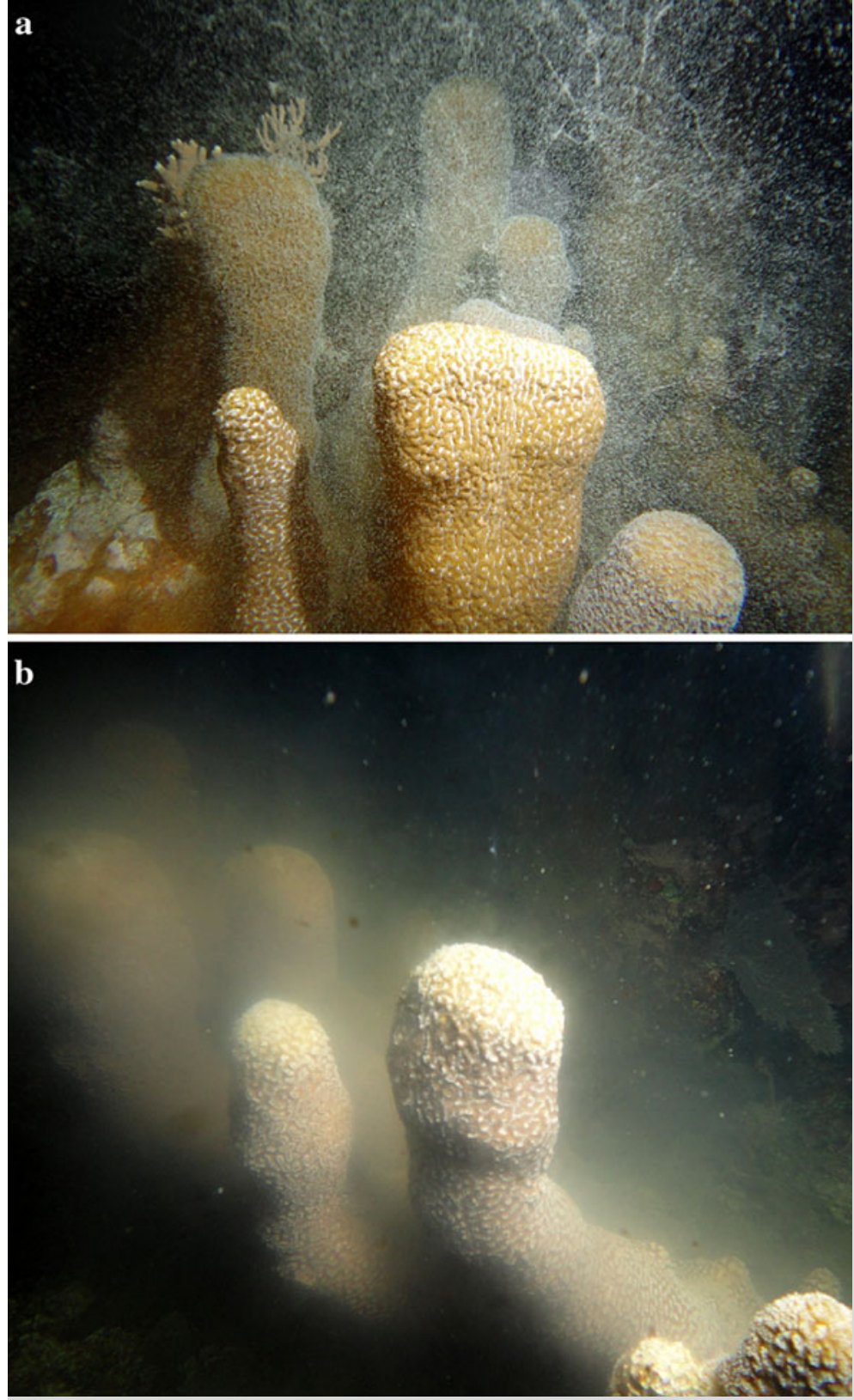

Fig. 1 Release of mucus strands containing individually buoyant eggs (a) and sperm (b) by female and male Dendrogyra cylindrus colonies Miller MW, Weil E, Szmant AM (2000) Coral recruitment and juvenile mortality as structuring factors for reef benthic communities in Biscayne National Park, USA. Coral Reefs
19:115-123

Szmant AM (1986) Reproductive ecology of Caribbean reef corals. Coral Reefs 5:43-53
The pillar coral Dendrogyra cylindrus has a patchy distribution throughout the Caribbean but is regionally rare in the Florida Keys. The species is a gonochoric spawner, with gametogenesis of both sexes previously documented between May and August in Puerto Rico (Szmant 1986). Spawning observations were made at a patch of $D$. cylindrus in $5 \mathrm{~m}$ depths at John Pennekamp State Park/Florida Keys National Marine Sanctuary following the two August 2012 full moons. Release of male and female gametes was observed between 2145-2200 hrs on the second and third nights following the 2nd August full moon (Fig. 1); no spawning was observed following the 31st August full moon. Males released gametes 1-10 min before females. An estimated $50 \%$ of the approximately 130 colonies at the site released large amounts of gametes the first night. Approximately $10 \%$ of colonies released smaller quantities the second night. These observations were concurrent with the regional spawning of Acropora spp. and match the timing of the only two previous $D$. cylindrus documentations: mid-August female gamete release in Puerto Rico (Szmant 1986) and male spawning at Looe Key (Middle Florida Keys) at 2150 hrs, 4 d following the August 2006 full moon (Donahue et al. 2008).

A lack of recent evidence to confirm recruits or juveniles of $D$. cylindrus in the Florida Keys (Miller et al. 2000; Miller 20002011) suggests an inherent rarity or recruitment failure. This first record of synchronous male and female spawning suggests that future genetic recombination and sexual reproduction of this proposed United States federally endangered species may be

Acknowledgments This research was enabled by NOAA Award NA10NMF4720029 to the Florida Fish and Wildlife Conservation Commission and conducted under permit in the Florida Keys National Marine Sanctuary.

\section{References}

Donahue S, Acosta A, Akins L, Ault J, Bohnsack J, Boyer J, Callahan M, Causey B, Cox C, Delaney J, Delgado G, Edwards K, Garrett G, Keller B, Kellison GT, Leeworthy VR, MacLaughlin L, McClenachan L, Miller MS, Miller SL, Ritchie K, Rohmann S, Santavy D, Pattengill-Semmens C, Sniffen B, Werndli S, Williams DE (2008) The State of Coral Reef Ecosystems of the Florida Keys. In: Waddell JE, Clarke AM (eds) The State of Coral Reef Ecosystems of the United States and Pacific Freely Associated States: 2008. NOAA Technical Memorandum NOS NCCOS 73. NOAA/ NCCOS Center for Coastal Monitoring and Assessment's Biogeography Team. Silver Spring, MD, pp 161-188

Miller SM (ed) (2000-2011) Quick Look Reports and Data Summaries. CMS/UNCW, Key Largo, FL. http://people.uncw.edu/millers/ regionally possible.

\section{Communicated by Prof. Rolf PM Bak}

K. L. Neely $(\bowtie) \cdot$ K. S. Lunz $\cdot$ K. A. Macaulay

Florida Fish and Wildlife Conservation Commission, Marathon, FL 33050, USA; e-mail: karen.neely@myfwc.com

Received: 20 December 2012/ Accepted: 15 March 2013/Published online: 30 March 2013

Coral Reefs (2013) 32:813

(C) Springer-Verlag Berlin Heidelberg 2013 